\title{
Documents on
}

\section{Women's Human Rights}

\section{and}

\section{Women in the $\not$ eace $\not$ rocess in Afghanistan}

compiled by Pamela Collett on behalf of the Afghan Women's Network Islamabad Pakistan May 1996 
Documents on

\author{
Women's Human Rights \\ and \\ Women in the $\bigotimes_{\text {eace }}$ Drocess \\ in Afghanistan
}

compiled by Pamela Collett on behalf of the Afghan Women's Network Islamabad Pakistan May 1996 
Surita Sandosham, Executive Director Equality Now New York, USA

Fax: 001-212-586-0906 copy: Nancy Hatch Dupre, ACBAR

Hermione Youngs, ERU

Gary Helseth, Save the Children (USA)

Pakistan/Afghanistan Field Office

\section{Dear Ms Sandosham}

I am sending the attached report to Equality Now, based on a request for information for the review of human rights in Afghanistan to be held by the UN in Geneva on 16 October 1995; forwarded to me by Nancy Hatch Dupre of the Agency Coordinating Body for Afghan Relief.

I am an educational consultant working with Save the Children (USA), Pakistan/ Afghanistan Field Office, Islamabad, Pakistan. We are currently developing female non formal education literacy programs in Afghanistan and refugee camps in Pakistan. Our staff is predominantly Afghan and we have field offices in Mazar-i-Sharif and Kabul. Staff go to and from Afghanistan on a regular basis, so we have up to date information on the situation in Afghanistan. I am also working with a group of Afghan women living in Pakistan, some of whom attended the NGO Forum on.Women in Beijing, who are trying to establish an Afghan women's network.

The following report is based on information from Afghan women living in Pakistan who have recently visited Afghanistan and/or have family and friends living in Afghanistan. The women who gave this information are from educated Kabul families. Most fled Kabul during the mujahadeen attacks on Kabul in 1992. The information about Jalalabad is from Hermione Youngs, director of women's programmes of Emergency Relief Unit, in an interview in Islamabad in September, 1995. ERU address is PO Box 69 GPO, Peshawar, Pakistan.

I suggest you contact Sarwar Hosaini, Programme Manager, Cooperation Center for Afghanistan (CCA) who organized a seminar on Women's Human Rights in Mazar-e-Sharif, Afghanistan 15-19 October, 1994. Sub office: CCA, H. No. 305, St. 25, D/4 Phase I, Hayatabad Peshawar, Pakistan. Tel: $++92-521-812530$

We would appreciate your keeping us informed regarding the review of the human rights situation in Afghanistan, specifically as it applies to women. We are particularly concerned about international opinion and influence in Afghanistan. There seems to be a trend for international support, either direct or tacit, for the so-called "Taliban" (students) as the force who can unify Afghanistan and end the civil war. The Taliban are opposed to human rights for women and have closed girl schools in Herat and forbidden women, except for a few health workers, to work outside the home. In response to conservative pressure of Taliban supporters, UN agencies recently suspended all their female staff working in Jalalabad. Thank you for your concern.

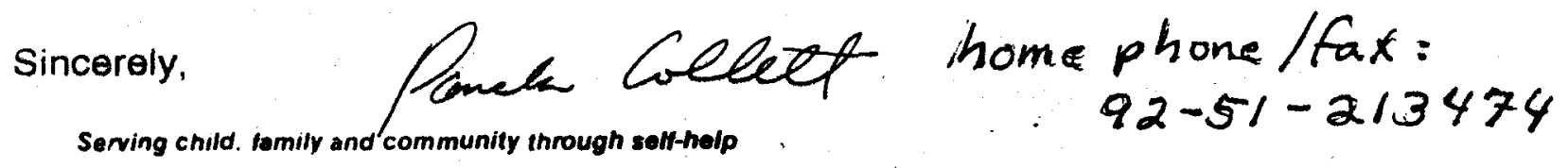


Report submitted to Equality Now, for the UN Human Rights Committee review of Afghanistan. to be held on October 16, 1995

\title{
Women's Human Rights in Afghanistan
}

\author{
by Pamela Collett, Educational Consultant \\ Save the Children (USA), Pakistan/Afghanistan Field Office \\ Islamabad, Pakistan
}

As noted in the Special Rapporteur's report to the UN in September 1994. Afghanistan does not have an effective central government. Administrative units are not the provinces but regions which are either governed by commanders or by councils (shuras). There is no central authority, judiciary, army, police or rule of law. Currently there are three principal groups controlling Afghanistan: Gen. Rashid Dostum in the north, the Taliban in the south and west and Burhanuddin Rabbani in Kabul. In September, 1995, the Taliban took control of Herat and are now threatening to take Kabul. Fighting has recently occurred on the outskirts of Kabul.

Recent visitors to Kabul report that although the situation is outwardly calm, people are frightened by the threatened attack by the Taliban. Many remember what happened in 1992. when the mujahadeen were fighting in Kabul and destroyed most of the city. Women and girls were not safe. Girls were abducted by commanders and forced into marriage, that is raped. Commanders were reported to have as many as ten "wives". If the girls or their families objected or resisted they were often killed. Many families sent their girls and women away, usually to Pakistan.

Some families in Kabul fear a repeat of the rape, torture and murder of 1992. One Afghan woman, currently living in Quetta, Pakistan described the women in Kabul after a visit in September 1995 as "like the living dead, with no hope for tomorrow. They are not sure what may happen in the next hour. They are afraid the war may start again."

Women in Kabul, especially educated women and widows who are more vulnerable, are afraid of a coming attack by the Taliban. They fear that if the Taliban come in to Kabul, they won't let the women go out of their homes. In other areas they have taken over, such as Kandahar and recently Herat, the Taliban have forbidden women to work outside the home and have closed all schools for girls. Boys' schools in Herat have also been affected because many of them have female teachers who have been forbidden to work by the Taliban. In areas under Taliban rule. some international NGO's have suspended work, because of their view that women's rights are human rights and development work is impossible without including Afghan women and girls.

Women are not allowed any freedom of mobility, of employment or of study under Taliban rule, who claim that all such activity is "un-Islamic". A visitor from Kandahar told a woman in Quetta, Pakistan that in Kandahar, a woman who went to the market alone was beaten by Taliban 
Report submitted to Equality Now, for the UN Human Rights Committee review of Afghanistan Women's Human Rights in Afghanistan by Pamela Collett page two

supporters and later died from her injuries. Although such stories cannot be independently verified, they do indicate the attitudes that Afghan women have toward the Taliban and their rule.

Almost all of the Taliban are from the Pashtun ethnic group (the largest ethnic group in Afghanistan which has traditionally dominated the military and government). Pashtun identity is based on a code of behaviour called Pashtunwali which include maintenance of female seclusion (purdah). Although Pashtuns label women working outside the home as "un-Islamic" their traditions are actually based on the Pashtunwali.

In Kabul and in Mazar-i-Sharif, women have some mobility and are working in cffices, schools, and government agencies. Women in Kabul and Mazar do not have to wear the hijab (veil). However, they still feel insecure as there are no institutions or legal protection of women's human rights. There is no security for any Afghans as armed militia are a law unto themselves. Women and men traveling in taxis outside of Mazar are often stopped and ordered out of the taxis by armed militia, so that the militia men can use the taxis for free transport.

In Taliban controlled areas, there are no rights for women to work, to go to school or even to go outside the home to shop or visit without being escorted by male family members. Afghan women and girls lack access to education and to jobs. Women cannot travel without being accompanied by male family members. Women that are going to work with a male driver if he is not a family member are stopped and questioned and harassed.

On a visit to Kabul in September, Hermione Youngs, director of the women's programmes of the Emergency Relief Unit (ERU), an NGO located in Jalalabad, saw a young woman wearing a thin head scarf, a long skirt and high heeled shoes walking along the street. She turned to her Afghan male companion and commented that if the young woman were walking in Jaialabad she would be in danger of being stoned. In an interview in Islamabad in September. 1995. Youngs commented that in her opinion, educated Afghans in Kabul don't want the Taliban. They believe that their country requires men and women working together to rebuild. Men and women are working together in offices in Kabul without any problems. Women don't have to wear the hijab. Women are allowed to be human.

Al though there are a few women in the government in Kabul: they are rarely consulted and are not part of the decision making process. No women have been consulted in the peace making process by the UN although Afghan women have questioned why they are not involved. One woman at a recent meeting in Mazar-i-Sharif, asked special UN envoy to Afghanistan, Mahmoud Mestiri, why he never spoke with women, who are the group in Afghanistan most committed to peace.

The Women's Human Rights seminar, organized by the Cooperation Center for Afghanistan ( $r$;C,A) held in Mazar-i-Sharif Afghanistan, 15-19 October, 1994, called for the UN to include women representatives in the peace talks and on advisory committees. The seminar passed 23 


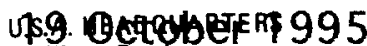

54 wititon naed

Westport, Connecticut 06881

To: UN Human Rights Committee

From: Pamela Collett, Education Consultant Save the Children (USA), Pakistan/Afghanistan Field Office

Subject: UN's role in ensuring women's and girls' human rights in Afghanistan

This letter summarizes two areas of concern regarding women's and girls' human rights in Afghanistan that relate to UN agencies. The first is the UN agencies' response to decrees by religious shuras banning women working outside the home and women and girls' access to education. The second is including women in the peace process in Afghanistan.

Having talked with several different sources who work with the UN, it seems that UN agencies have not taken a clear stand regarding decrees by some local Afghan religious shuras (councils) that women should not be allowed to work outside the home and that women and girls should not be allowed educational opportunities. These religious shuras are local, all male, self-appointed bodies that do not represent the majority of the Afghan population. The local Afghan population is not consulted in their decision making and women and girls have no representation in these shuras.

There is disagreement within the UN agencies about how to respond to shuras' decrees denying women and girls' human rights, but the current prevailing view seems to be, take a low profile, accept the decrees, and wait and see if the shura will change their minds. One area some shuras seem to be reconsidering is in the area of health, since as one UN official said, "They don't want men delivering babies." This "wait and see" policy being followed by some UN officials and agencies would seem to be accepting that women and girls' human rights are expendable and depend on what minority, all male religious shuras decide to grant to some women in some areas, such as health.

Peter Hansen, UN Under Secretary General for Humanitarian Assistance and Emergency Relief, in a press conference in Islamabad on October 8, 1995, said that he had been assured by the governor of Kandahar, Afghanistan (an area under Taliban control), that girls will be allowed access to education "within the Islamic framework". This assurance made no comment about women's rights 
Report submitted to Equality Now, for the UN Human Rights Committee review of Afghanistan Women's Human Rights in Afghanistan by Pamela Collett page three

resolutions, including the protection of special groups of women such as disabled, widows and the displaced and against any decrees contrary to women's human rights.

During the period in 1992 of mujahadeen attacks on and occupation of Kabul, no young woman was safe. If seen, a man would demand her "in marriage" that is for his sexual pleasure. so families kept their girls inside or sent them away. Militias controlling a certain territory would rape, torture and kill any woman from a tribe or ethnic group different from their own. During this period. women had no reproductive rights. All contraceptive drugs were destroyed by the mujahadeen, because they were called "un-Islamic". If any women or girls were seen on the streets in clothing that the mujahadeen considered "improper", they were warned that if it happened again they would be punished. Guards were posted in every office watching women. how they dressed, and how they behaved. Women were told they must wear hijab (veil) and could not wear makeup.

There is no right of safe return to Afghanistan for women, especially widows. Widows have no protection, no right to employment or benefits and no guarantees of security. Women could be targeted for revenge killing by a particular party or tribe or if they are educated because they are sometimes labeled as "communists". Widows living in Pakistan whose husbands were members of the former communist-backed regime cortsider themselves to be in great danger of execution if they try to return to Afghanistan. Widows in Afghanistan are often forced to marry their brotherin-law or other relative in their husband's family. In a village near Mazar-e-Sharif, village women claimed that a year ago a widow was hung for refusing to marry her deceased husband's cousin.

In Kandahar, Jalalabad, and Herat, ulema shura (all male religious councils) have decided that women, except for a few health workers, cannot work outside the home. Afghan community health workers employed by Emergency Relief Unit, an NGO in Jalalabad, have been harassed by shura members for working in the displaced persons camps. One female health worker who was being driven to a camp was stopped by local militia and her driver was arrested for suspicion of immoral activities (that is driving a car with a woman in it, who is not related to him). The woman was also threatened. Another female health worker had to flee from Jalalabad to Kabul after repeated threats because she did not wear the hijab (veil).

In July 1995, the ulema shura in Jalalabad forbade the 300 female community health workers employed by ERU to continue working. Earlier in the year, the UN suspended all of their female Afghan employees, from office workers to cleaners, on the order of the religious shura. When the ulema shura said that they would not allow the female health workers to continue their work in Jalalabad and in the displaced persons camps, Hermione Youngs, the director of women's programmes of the ERU, suspended the sanitation program which employed 2,000 men. When the men complained to her, she told them to talk with the mullahs and the shura. Because of community pressure to restore the sanitation program, on the first of September 1995 she was told that she could reopen the female community health program as long as the female health workers dressed and behaved appropriately, that is wore the hijab and didn't wear any makeup. 
Report submitted to Equality Now, for the UN Human Rights Committee review of Afghanistan Women's Human Rights in Afghanistan by Pamela Collett page four

In August 1995, 500 Afghan women met in Kabul to discuss women's issues in preparation for the UN Fourth World Conference on Women in Beijing. After giving his approval to the conference in a speech supporting women's rights, including the right of women to employment, the Rabbani government in Kabul gave in to internal and external conservative pressure from groups opposing women's human rights. Just a few days before the conference was to begin on 4 September, 1995, the Kabul government prohibited the twelve member Afghan women's delegation from going to the UN Fourth World Conference on Women, saying that the conference would promote behaviour that is immoral and "un-Islamic". The only Muslim country that did not register for the UN women's conference was Saudi Arahia.

One Afghan woman from Kabul summed up the situation by saying that women have no human rights in Afghanistan; women have no protection, no guarantee of personal safety and security. In the past, many Afghans assumed that women would be protected by the cultural traditions that respected women as wives and mothers. However, with the disintegration of society during the long period of civil war, traditions which had established some respect for women have disappeared. Because no women's human rights have been institutionalized, that is given a legal basis, women have nothing to fall back on and no protection.

The UN Human Rights Committee is urged to investigate the situation of women's rights in Afghanistan and to monitor the peace process to ensure the active participation of Afghan women and the institutionalization of women's rights in any transitional accords. The UN Human Rights Committee should consider appointing a female counterpart or a special commission to work with UN Special Envoy Mahmoud Mestiri which would concentrate on making contact with Afghan women from all ethnic, tribal, religious groups and social classes to ensure that their positions on peace and human rights could be given due consideration. A lasting peace is not possible without the active participation of Afghan women. 
To: UN Human Rights Committee

page two

From: Pamela Collett

Subject: UN's role in ensuring women's and girls' human rights in Afghanistan

to employment and education . Furthermore, as it is the Taliban's particular interpretation of Islam which they have used to justify restricting women to the home, this assurance which Hansen received does not guarantee that women's and girls' human rights will be acknowledged by the Taliban. Currently there are no girls' schools in the Kandahar area.

The question is should UN agencies continue programming which benefits only males and/or employs only males in accordance with the shuras' decrees? Several donors to Afghanistan, some international NGO's, and many Afghan woman I've spoken with do not agree with this policy. They think that UN agencies should not accept denial of women's human rights in order to have groups like the Taliban's approval to continue programs that benefit and employ Afghan males and exclude women and girls. If Afghan women and girls are not included in programs and are not allowed to work for the UN and international NGO's, most of the people I have spoken with suggest that all UN and international donor programs should be suspended in those areas where the shuras have decreed that women cannot work, except for the most critical relief and emergency health care work.

UN agencies need to discuss and clarify their support for women and girls' human rights in this situation where self-appointed religious shuras who are not representative of the majority opinion deny women's and girl's basic human rights. The UN should not acquiesce and suspend female staff and programs. To do so would be in violation of the UN Charter, the Universal Declaration of Human Rights and CEDAW.

Regarding the peace process including Afghan women: there has been no serious attempt to include women. The UN special envoy, Mahmoud Mestiri did meet with and listen to Afghan women in Peshawar, Pakistan, but I have not been able to find evidence of any concrete proposal to include Afghan women in the peace process, despite the fact that there are an organized group of women in Mazar-i-Sharif who are ready to participate as well as women in Kabul who participated in the preparatory conference for Beijing. 
To: UN Human Rights Committee From: Pamela Collett

page three

Subject: UN's role in ensuring women's and girls' human rights in Afghanistan

I spoke off the record with a representative of General Dostum's government in Islamabad on October 18, 1995. He claims that he has submitted a proposal for including women in the peace process to the OIC (Organization of Islamic Conference) who have a special mission for the peace process in Afghanistan, located in Islamabad. He said that the OIC were willing to consider including women. He said that when he mentioned it to the UN, they said there were no mechanisms for including women and that it was impossible because groups like the Taliban would not allow it.

The energy and commitment of Afghan women, who represent at least the half of the population, are not being heard, while a small minority group, the Taliban, are represented because they have military strength. Excluding women does not seem a firm basis on which to build a lasting peace in Afghanistan.

To repeat the recommendations in the report entitled "Women's Human Rights in Afghanistan", the UN Human Rights Committee is urged to investigate the situation of women's rights in Afghanistan and to monitor the peace process to ensure the participation of Afghan women. The UN Human Rights Committee should also investigate UN agencies operating within Afghanistan regarding their position on the shuras' decrees prohibiting women's employment outside the home and women and gir!s' access to education. 


\section{Women Being Forced From U.N. Workplaces in Afghanistan}

\section{BY BARBARA CROSSETTE}

UNITED NATIONS - Women are being forced out of United Nations workplaces in Afghanistan because self-appointed conservative Islamic councils are threatening to attack the women and the offices.

$\therefore$ In Jalalabad, where United Na. tions agencies are caring for more than 100,000 Afghans recovering from civil war, at least three United Nagitions offices have kept women home rather than risk the collapse of their programs, officials said.

An orthodox Islamic movement known as the Taliban is said to be behind the effort to keep women from office cleaners to engineers, teachers and health workers - in their homes.

The enforcers are local groups called shuras, which are mobilizing mobs to assault women on their way to work at international agencies or volunteer organizations and sack the offices that employ them, officials say.

Peter Hansen, head of the United Nations Department of Humanitarian Affairs, said some Afghan women were continuing to work at home or were on paid leave until their contracts expired. But he acknowledged that they risked losing their jobs permanently if a compromise could not be reached.

He said the confrontation posed a "terrible dilemma" for United Nations agencies including the High Commissioner for Refugees and Unicef, as well as other agencies work ing in the country.

Private organizations working in Afghanistan and human right groups are outraged by what they see as the willingness of the United Nations to abandon women for the sake of smooth relations with rell- gious conservatives.

"It doesn't shock us so much what the Afghans do," said Surita Sandosham, executive director of Equality Now, a New York-based group that helps women organize rights cam. paigns around the world. "What is shocking is that U.N. bodies are acquiescing." Equality Now has lobbied to take the case to the United Nations Human Rights Committee.

In a letter to the committee, Pamela Collett of the Pakistan-Afghanistan field office of Save the Children, said, "The question is, should U.N. agencies continue programming which benefits only males and/or employs only males in accordance with the shuras' decrees?"

Mr. Hansen, who recently returned from a trip to Afghanistan, said he had met with militants now in control of the southern city of Kandahar to discuss reports that they had closed all schools to girls.

He said he had told them that women's rights were human rights and that unless they accepted international norms, they would lose international support. He said they had assured him that girls would get an education in keeping with what religious practice allows.

Ms. Collett said in her letter to the Human Rights Committee that the Taliban's pledges were suspect.
"As it is the Taliban's particular interpretation of Islam which they have used to justify restricting wom en to the home," she wrote "this assurance that Hansen receive, "this not guarantee that womed does girls' rights will be acknow's and The Taliban have acknowledged." ities Talban have captured several cities in Afghanistan and are now poised to attack Kabul, the capital. But things in Government-held areas are not much better, women's groups gation september the Afghan deleence on wome Fourth World Conferhibited Women in Beijing was prohibited from attending at the last minute because the Government demote "immoral the gathering would prohavior." 


\section{PRESS RELEASE}

\section{GIRLS EDUCATION IS A IIUMAN RIGIITS ISSUE}

The Unitcd Nations Children's Fund (UNICEF) announced today that th had decided to suspend assistance to celucation programmes in those parts of Afglanistan where sonme local Taliban authoritics laad cxcluded girls from educational opportunities by colosing sclools.

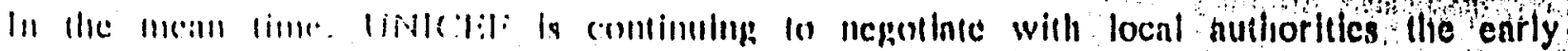
resumption of educitional epportunitics for nll girls afrected by the closuro of schools. This: had occurred only in scimc of the arcas controlled by the Taliban.

In laking this position. UNICEF Executive Director, Ms. Carol Bellâny, saidu UNICEF abicles by the anti-discrimimation principles of the Convention on the Rights of the effild ratified by 181 couneries, including Arghanlstan". Article 2 of the Convention statestliats "States partics shall respect and cnsure the rights set forth in the present Convention to each" child within their juriscliction without discrimination of any kind, irrespective of the chllds or his or her parenl's or Icgal guardian's race, colout, sex, languagef religionily political or

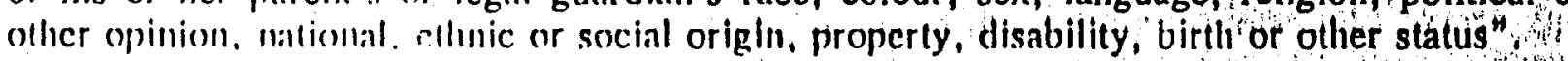

Ms. Bcllamy said "lle frinciple of non discrimination has guided UNICEF's work slnce Its inception ncarly fifty years ago when the organization decided that its assistance would only be provided if it coula! bencfit children on all sides of a political conffilde UN UNCEF, is committed to girls' clucation as a human right".

In addition to its assistance for cducation, UNICEF spends close to US\$ 9 million a year in health, water and sanitation. These programmes, as well as education programmes not. affected by the closutes, will continue since they benefit both girls and boys

UNICIEF cmploys 23 fomale staff for ils programine in Afghanistan, Contraty to press reports it has tecilher lorminated llicir employment nor restricled their movements nor does it intend to do so.

lor further information please contact:

Jeremy IIntley, Iiroimation Officer, UNICEF Afglianlstan Programme; Pestiâyar Trl: (521) $\$ 43310,840496$ 


\section{Women's human rights in Afghanistan}

\section{Pamela Collett}

$\mathrm{F}$ ront page headlines every day talk of the battles going on in Afghnnislan. Hitt whint is linjuening with the pouple in Afglianistan, particularly the women, who have suffered the most in this ongoing civil war? Nithough there are regular reports and concem about violatlons of women's human rights in Bosnia and Kaslumir, very little attention lins been focused recently on what is happening to wonen in our neighbouring country, Afghanistau. Recently, in Geneva, the $\mathrm{U}^{-}$uman Rights Comniltee was sc...ulued to review Afghanlstan's liuman rights record.

Recent visitors to Kabul report that although the situation is ontwardly caim, people are frightened by the threatened altack by the Tallban. Many remember what happened in 1992, when the mujahideen were fighting In Kabul and destroyed mosl of the city.

Women and girls wero not sne. firls were abducted by commaulers and forced into marriage, that is mped. Comnuanders were reported to have as many as ten "wives". If the girls or their families objected or resistell they were often killed. Many families sent their girls and women away, often to Pakistan.

Sone families in Kabul fear a re. peat of the violence of 1992. One Nghan woman, currently living in Quetta, Pakistan described the $\checkmark$ ven in Kabul after a visit in 1. enber 1996 as "like the living ilead, witl tho hope for tomorrow. 'licy are not sure what nay happen in the wext hour. They are afraid the war may start again in Kabul."

In Kabul and Mazar-l-Sliarif women are working in offices, schools and governnent agencles. Ilowever, they feel insecure as there are no Inatitutuons or legal protection if women's human tighis. Mnny women in Kabul, espechally educated women and widows, who feel they are more vulnerable, fear that if the Thliban come in to Kabul, they won't lat the women go out of thicir homes. In Kandaliar and Herat, the Thliban - have dorbyducen women to work oul-.. side the fome'tund harercloscd nll

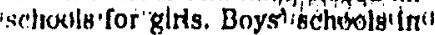
llerat have also been affected, be. cause many of them have female teachers who have been forbidden to work by the Taliban. In areas under Taliban rule, some international NGO's have suspended work, be'ause of their view that wonien's rights are human rights and development work is impossible without including Afghan wonien and girls.
Most of the Thation are Pishtums, which is the largest pthmir grnmp in Afglunistan. Identity for many Ihwill. tuns is based on the cotile of be. haviour called Pashtomwali which includes maintenance of feinale seclusion (purdali). Althumgh some Pashtuns label women working outside the home as "un-Isliunic", their traditions are actually bascil on the Pashitunwall.

Female Afghan commmmity health workers eniployed by Finergency Relief Unit, an NGO in .Jaladaliad, lave been harased by slura members for working in the displacel persons comps. One femnle henlth worker who wha behng ditven to a camp wing stopped by loeal miltin nud her ditiver was arrested for susplicton of immoral activities (that is driving a car with a woinan it it, who is nol re. lated to him). The woman was also threatened.

In July 1995, the nlema shura In Jalninind forbade the :ion frnmale coimmunity health workers enuployed by ERU to contunue working. Farlier in the year, the UN suspended all of their female Afglan employees, from office workers to cleaners, on the order of the religious slum. When the shura salil that they would nort allow

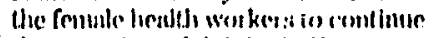
thelr work fit Jnhalond, llermiens Youngs, the director of women's pro. gramnies of the EIRU, responded by also suspending the sanitation pro. gramme.which employed 2,000 men. When the men coinplained to her, she told them to talk with the minlahs and the shura. Because of colnmunity pressure to restore the satititusem pro. gramme, on the first of September 1995 she was told that slie could roopen the remale comınumily health programme as long as the female healuh workers, dressed and lechaved appropitately, that is wore tive hijob and dicln't wear ay inakeit]).

There is no right of safe retirn to Afghanistan for women living in Pakistan, especially widows. Widows lave no protection, no right to employment or beneflts and no marantees of security. Women conuld be tar.: geted for revenge killing by a particular party or tribe or just berause they are colirnted. Wilows liv. ling in lykistun whose husbands were minubers of the fonmer conmunist. backed regime consider themselves to be in great danger of execution if they try to return to Afghanistan. Widows in Afghanistan are often forced to marry their brother-in-law or other relatfve in their husband's fanilly. In a vlllnge near Mazar-l. Sharif, village wonnell claimed that $\mathrm{a}^{\text {? }}$ year ago a widow was hing for re: fusing to marty her deceased husband's consitit.
The UN flumian RIglits Comunitier Ls utyed w lnvestighte the situation of woinen's rights in Afghanistan aul to. inonitor the pence process to ensure the active participation of Afghan women and the institutionalisation of women's rights in any transitional ac. cords. The UN Human Righis Comniltec should consider appointing a female counterpart or a special comInissloit to work with UN Speclal Envoy Malumud Mestirf, which rould concentrate on making contact with Afghai woinen from ail ethunc, tribal, religious groups and socinl classes to cnsure thint their positlons on peace and luman ights glven due coisidemiloil. A lasting peace is not possible without the active participation of Afghan women. (alks and on alvisory comm peace talks and on advisory con tees. The seminar pisssed 23 resolutions, including the yrotection of specinl groups of women such as: disnbled, wiflows nud the dlsplaced nud agahlist any decrees contrary to women's huma!ı righis. The seminar also called for protecting wonien's rights through the presence of women in future leglslative bodles, securing through legisiation the rights of women to select : their: spouse, lis riglit of ownership and other social rights in ncrordance with slamic principles, and that men pro. vide equal opportundiles for care and education of female and male chil-

Iin Aliphist I995, 500 Afghai women met in Kinbul to discuss womeris dssurs in pryparation for the

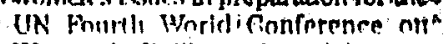

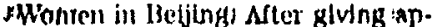
proval to the conference in a speech supporting women's rights, including the riglit of women to employment the Rablianl govermiment in Kabul gave in to intermal and exterrial press? sure frou grroups opposing women's humar righis. Just a few days before the conference was to begin on September 4, 1995, the Kabul govcrnment prohibited the twelve member Afghun wonen's delegation from golng to the UN conference on Worren, saylng thit the conference would promote beluavlour thai is immorni and "un-Islamic". The only Mublin country that did not register for the UN Conference on Women was Saudl Arabla. Mary Huslim countries, Including Pakistan, were active parilcipants in the NGO Fonum and the Fourth World Coiference on Women. : Prime Minster Benazir Bhutto was one of the featured speakers al the conference.

One Afglian womian from Kabul stummed up the situation by saying that wonicn have no human rights in Afghanlstan, women lave no protecUon, no guarantee of personal safety and security.

In the past, many Afghans assumed that women would be pro-? lected by the cultural traditions that respected women as wives and moth." ers. Ilowever, with the disintegration of soclety during the long period of civil war, traditions which had established some respect for women have dlsapjeared. Because no women's hunian rights have bcen institutionalised, that is given a legal basis, women have notling to rall back on ninil no prutertion.

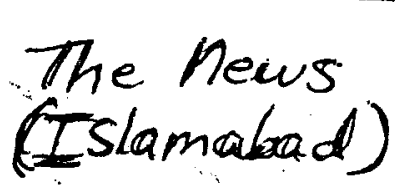

11 November 1993 

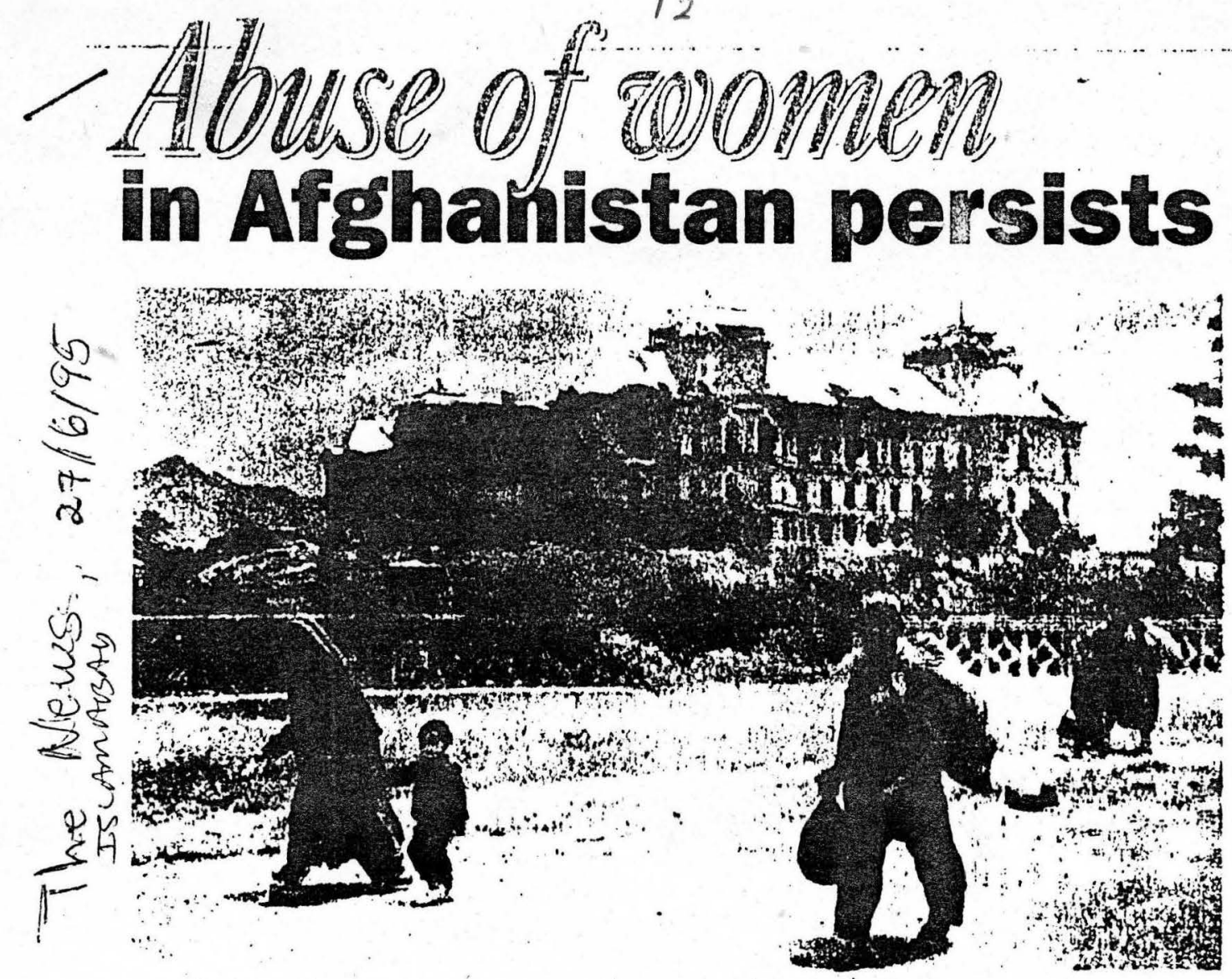

By Iram Noor

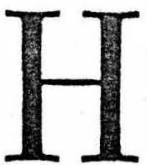

istory repeats itself time and time again and few learn the lessons it teaches. There are Emergency actions, $\mathrm{P}_{(\mathbf{0}}$ lice actions, wars or revolutions, each leaving a story in the aftermath - a story of blood and gore, of pain and anguish. Afghanistan has been in the throes of a bloody civil war for three years now and those who have-lived to see the ravages are hundreds of thousands of Afghan women and children. As in any war it is, the latter that are made victims and their honour, security and basic human rights are left in shreds. It is women whom men use and abuse to gain whatever power they can over any opposition that stands before them. It is the lives of the innocent, the women and the children, that have been left shattered since the Mujahideen assumed power in Kabul, in the April of 1992 . It seems as if the Afghan leaders who have been locked in a bloody conflict for quite sometime now are not interested in peace. None realize the heavy price Afghanistan is paying nor do they feel any guilt or remorse about the sufferings and sorrows they are inflicting on the innocent, the helpless and the hapless.

Women and children, being the main victims are killea or maimed in what appears to be deliberate artillery attacks on civilians. And these attacks do not seem to be restricted to artillery firing and bombings. Instead there have been accounts of women being ab-

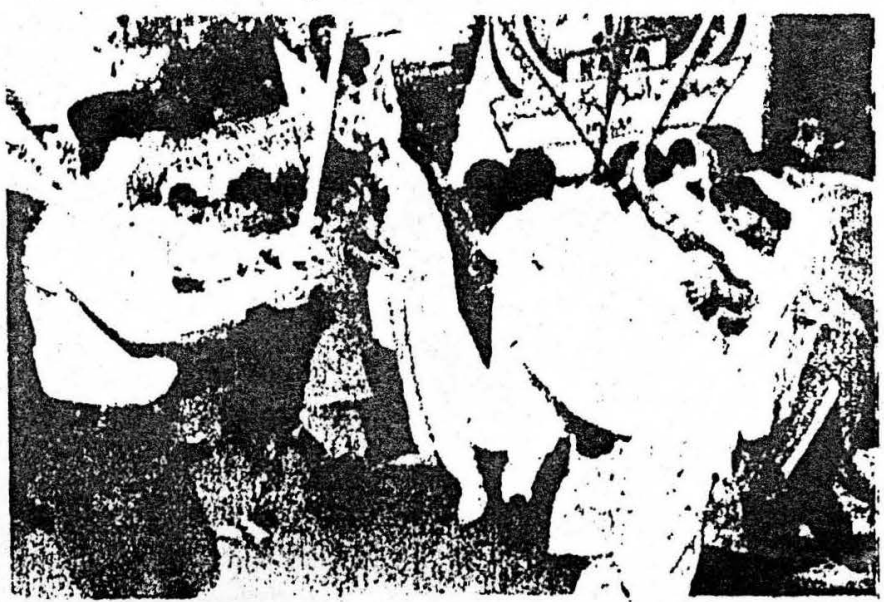

killed by unexpected attacks on their homegifn-roterbes1994, Qala Fataullah, a district of Kabul, was hit by a series of bombs, one of which exploded in the grounds where a wedding ceremony was taking place. As a result of this 70 people were killed. Women who resisted abduction or rape were brutally killed by Armed Political Groups'. These warring factions have no regard for human life and have killed daughters in front of their parents.Some Mujahideen groups have reportedly cele. brated military victories in resiclential areas, showing no concern about the destruction of homes or the killings and wounding of unarmed civilians".

Another tragedy of war are the stories of defilement of women. Here it is going on unabated. Rape of women by armed guards belonging to the various warring factions appear to be condoned by leaders as a method of intimidating vanquished populations and of rewarding soldiers.

Some armed guards target women from ethnic minority groups whom they regard as enemies. "In March 1994 a 15-year-old girl was repeatedly raped in her house in Kabul's Chel Sotoon district after armed guards entered the house and killed her father for allowing her to go to school", says another report by $A . I$.

"Several Afghan women have reportedly committed suicide to avoid being raped. In at least one case, a father who saw Mujahideen guards coming for his daughter reportedly killed her before she could be taken away", is yet another story of pain and plunder.

The reports being filed stitte that "It is depressing to know that Afghan women and young girls have suffered the fate of being abducted and detained by Mujahideen groups and their commanders (1) be used for sexual purposes or sold into prostitulion. Most have been victimizd liy commanders or Continued on page 4

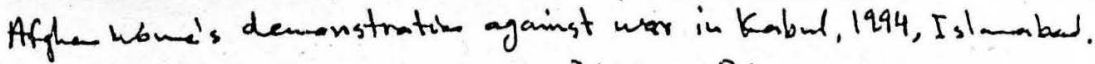

$$
\begin{aligned}
& \text { The quanp was baedly beaten by Pakistari Police. }
\end{aligned}
$$




\section{Fietus killing: \\ Continued from page 1}

bring about a complete change in traditional norms, customs and practices that have loen held onto and which lrelong to a bygone age. To do so one 1 must go about removing such ern-

y straints from a society which compels a woman to destroy her fetus. The only way this will ever happen is

when the prinary requisite is understoxd and something is done about it - by educating the massesl By systematically alleviating poverty, helping women to be independent and able (1) stand on their own two feet and not always to be fintancially dependant on men, should be the initial details to target. In India, or for that matter the sub-continent, what is required is to eliminate the menace of duwry, women being treated as commodity and that too of no value. And if, in the Third World, legislation is what they need, then let them legislate against men's abnormal behaviour towards women, men's degrading attitude towards women and legislate against the unlimited power over women, that men enjoy.

But for things to be different wornen will have to take the onus and to work harder. For, as in the past, it should no longer be, or remain only 'a man's world' as in a man's world a woman has no place except the place that a man so determines for her.

\section{in Afghanistan persists}

Continued from page 1 guards allied to an opposed faction, because they belong to a particular religious or ethnic group. One woman reported that her 13-yearold niece was abducted by wuards of a hazb1993. A woman who fled Kabul in January 1994 saw armed guards whom she be1 lieved to be members of General Dostumis forces taking away young girls and boy's".

Women's organisations have also not been spared, says the $A . I$ report. The Revolutionary Association of the Women of Afghanistan (RAWA), which works for women's rights, has been systematically attacked. It is alleged that Mina Keshwar Kamal - a founding member of the RAWA - was assassinated in February 1987 in Ouetta, Pakistan, reportedly by nembers of an Afghan Mujahideen group. Other leaders of the association have been threatened with death. Another organisution The Afghan Women's Council' (AW'C) headed by Fatama Gilani, has also been threatened by some $\mathrm{Mu}$ jahideen groups.

The horrifying brutality has devastating elfects.

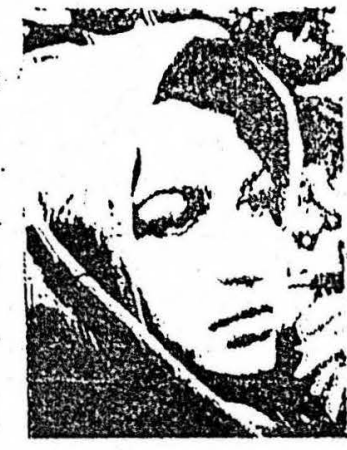

Hundreds of women are traunatized by the herrific abuses they lave suifered or witnessed i.e. mothers have been forced to watch their young daughters being raped. Girls have witnessed their parents being brutally beaten or killed. Thousands of women have had to watch helplessly as their hounes are destruyed. Not surprisingly, many of these women are severely traumatized and in desperate need of help.

The unbearable misery has forced hundreds of thousands of Afghan women, along with thei families, to leave their homes in order to finc refuge from the terror and abuse that dog their footsteps. Along their way to safety, they have suffered terrible hardships.

The horror and tales of woe do not end on arrival at refugee camps states the Amnesty International report. "On arrival they have to bear with grossly underecuipped refugete camps where many are still not safe from attack. Most families said they had to pay money (1) pass from one territory to another, irrespective of their political leanings.

In Pukistun", says the report, "the refugee camps are often controlled by one or other of the warring Afghan factions and women have been attacked, particularly. those who are unaccompanied loy mer".

Alongside these appalling conditions, women in

Afghanistan have been prevented froin exercising some of their fundamental rights including the rights to association, freedom of expression and employment by Mujahideen groups who consider such activities to be un-Islanic for women.

Afghanistan's constitution which guaranteed fundamental rights to women was suspended in April 1952 when the Mujahideen groups took power in Kalsul.

The legal system existing before 1992 has been ignored by warlords and the judicial structure has been largely dismantled. These who perpetrate human rights violations and abuses

do so with virtual inpunity. In several provinces, warlords have assumed the functions of judges: in some other provinces Islamic clergy or majlis-e-shooras assume judicial functions.

In some of these provinces,
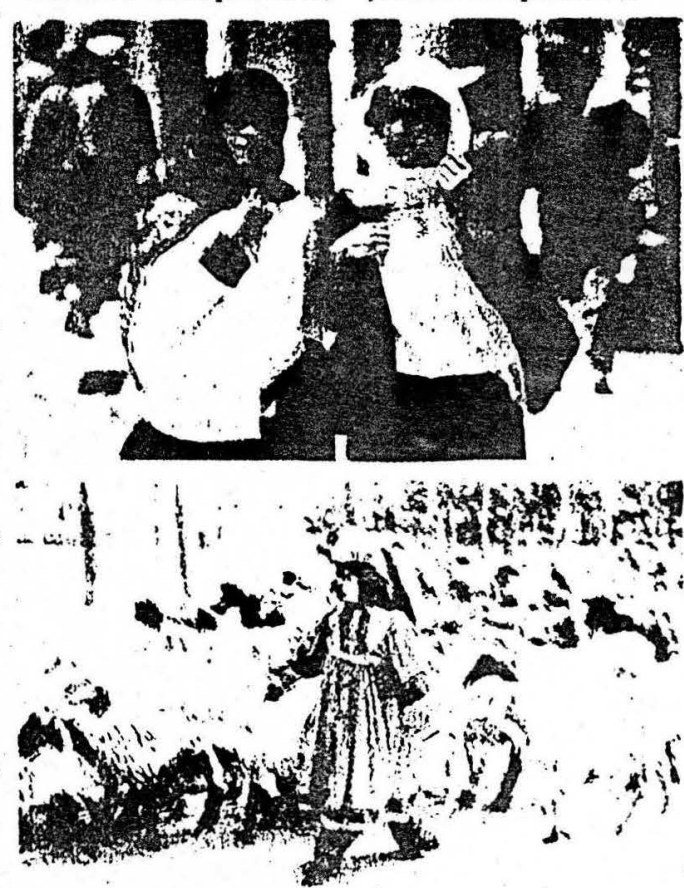

trials which fall far short of internationally accepted standards of justice have reportedly resulted.

The human rights catastrophe in Afghanistan demands immediate action from the world community. It is a moral duty to prevent warring factions in Afghanistan from committing human rights violations such as have been wont to happen these past few years. It is imperative to 
Created on $11 / 10 / 95$ by LBY Xmitited on $11 / 10 / 95$

Addr/Prod: 3 (YDB RNA

TOPIC: 4 (AF DIP EMRG LDC

BC-AFGHAN-UN-WOMEN ISTLD (SCHEDULED) (PVS ${ }^{-N E W ~ Y O R K) ~}$

UN agency halts Afghan ops over girls ochools

(Updates with UNICEF statement, changes dateline)

By Robert Evans

GENEVA, Nov 10 (Reuter) - The United Nations childrens' agency UNICEF announced on Friday it was suspending help for education programmes in Islamic militant-controlled areas of Alghanistan where girls' schools were boing closed.

The move came as human rights groups in New York alleged that U.N. agencies including UNICEF were cutting back on women staff at lhe demand of the Taleban movement which controls much of the soulh and west of the country.

A UNICEF spokeswoman told reporters the decision had bcen taken by the New York-based agency's new Executive Director, carol Bellamy of the United States, in accordance with the U.N. Convention on the Rights of the Chjld.

She quoted a statement from Bellany as saying UNICEF was commitced to girls' education as a human right.

"The principle of non-discrimination has guided UNICEF's work since its inception nearly 50 ycars ago when the organisation decided that its assistance would only be provided if it could benefit children on all sides of a political conflict," the statement. added.

The spokeswoman, Marie Heuze, baid the move was limiled to the south and weat around the cities of Jalalabad and Herat which are run by the Taleban, a well-armed fundamentalist militia movement $f$ jghting to oust the present Afghan government UNICEF was ncgotiating with the Taleban, which is demanding the resignation of President Burhanuddin Rabbani in Kabul, "for the resumplion of educational opportunities for all girls affected by the closure of schools," Heuze added.

She said the agency employcd 2.3 female staff in Afghanistan. "It has neither lerminated nor restricted their movements, not does it intend to do 80 ," she added.

Earlier in New York, other U.N. officials said charges by human rights groups that: some agencies of the world body were caving in to Taleban pressure on cmploying women were exaggerated.

But they admit.ted that some self-appointed Islamic councils in Jalalabad province have threatencd to attack Afghan women working in certain office or profcssional jobs.

"No woman in U.N. employment has been fired," said peter Hansen, the undersecretary-general for humanilarjan affairs. "There werc cases where contracts could not be renewed because the women were hindered by local authorities in attending work," he said late on Thursday.

"In. such cases, the United Nations has gone to great length to have that work carrjed out in their homes but that also has been obsilructed by local authorities." he added.

Equality Now, a New York-based women's rights group, has compiled information from private rejjef groups in Afghanis:an and submitted lhem to the Gcreva-based Human Rights comititee.

Included was research from the Pakistan-Afghanistan Save the children field office saying U.N. agency officials in Jalalabad appeared to have laken decisions alfecling women on their local staff without approval from headquarters.

NOU-16-1995 11:52 +212 355 6143 
However, the World Food Programme, anothes U.N. auency, acked a private group it funded, thic Energency Relief unit. ER(1), which thrcatened to shut down operations in Jalalabad if ts femle health workers werc barred from conployment.

"What chance do non-governmental groups have if the Uniter ations staff do cxactly what the religious shuras ask?" said ermione Youngs of the ERU in Jalalabad - - where the U.N. is aring for more than 100,000 displaced Afghans. REUTER 
Created on $11 / 10 / 95$ by RHEA

Addr/Prod: $4 ; N Y$ W UNS SINY

BC - AFGHAN - UN - WOMEN

Afghan women aid cut from UN jobs in Afghanistan

By Evelyn Leopold

UNITED NATIONS, Nov 10 (Reuter) - Under pressure from Islamic militants, some U.N. agencies in Afghanistan are culling down on women staff, human rights groups charge.

- U.N. officials say the accusations are exaggerated but admit. some self-appointed lslamic councils in Jalalabad province, have threatened to attack Afghanistan women working in certain office or professional jobs.

"No woman in U.N. employmenl has been fired," sajd peler" llansen, the underbecretary-general for humanitarian arfairs.

"lhere were cases where contracts could not be rencwed

br -ause the women were hindered by local authorities in

a. ending work, " he said in late on Thursday.

"In such cases, the United Nations has gone to great length to have that work carried out in their homes but that. alsa has been obstructed by Jocal authorities." he added.

Equality Now, a New York-bascd women's rights group, has compiled information from private relief groups in Afghanistan and submitted them to the Geneva-bascd Human Rights Committec. Inc:luded was research from pamela collett of the Fakistan-Afghanistan Save the Children ficld office, who said it. appeared U.N. agency djrectors in Jalalabad took decisiurs agajrist their Jocal staff without approval from headquartera.

Aniong them were:

- the U.N. Office for Coordination of Humanitarian

Assistance lo Afghanistan assured Jalalaban authorities it had no Afghan women on its staff after dismisaing four of them, two engineers and two cleaning staff.

- UNICEF, the U.N. Chilarcns Fund, laid off lwo fcmale office employees without pay last may after a letter from lho Jucal c:ouncil or shura. Another woman left a job to join

U CEF before May but was never contacted afterwards.

- lhe U.N. High Commissioner for Refugees suspended arl Afghan office workex in May with pay.

llowever, the world Food Prograll, another U.N. agency, backed a private group it funded, the Emergency Relief Unit (ERU), which threatened to shut down operalions in Jalalahad if its female health workers were barred from employment.

"Whal chance do non-governmental groups have if the Unitcd Natjons staff do exactly what the religious shuras ask, "said Hermionte Youngs of the ERU jn Jala] abad.

Another official for a U.N. aid agoncy, who asked not to he named, sajd his group was discouraged by personnel in New York from siendjng women to Afghanistan for "security reasons."

The United Nations is caring for more than 100,000 Afghans in Jalalabad slowly recovering from years of civil war. The province, and many other areas of the country are contolled by the orthodox Tabjlban movement.

Its jalalabad backers are forbidding womer to work oulsido the home except for some educationa]. and health jobs.

Hansen, after a trip to $\Lambda$ fghanislan last month, warned line 'laljban that donor countries would cut support if they folt "women and girls were not being given an equal chance." some gir]s schcols had been closed, education was unequal and women were restricted to health and educational fields. 101-10-1995 $11: 50$ $+2123550143$ 
Michael koss, New York spokesman for the world Food rogram, said, "We are involved in alot of male-dominated 1) tures, especially when it comes to food" because men want 2 sell it off, sometimes in exchange for arms.

The aim, he said, was to give food directjy to women "in ne belief that this is they way of assuring the children will :tually get it." 
28 November 1995

Mazar-i-Sharif Afghanistan

Dear sister Judge Elizabeth Evatt

Hello

Let me first express my gratitude and thanks for the protest that you did on behalf of the Afghan women against the action that the United Nations agencies that expelled women from their jobs according to the decision of the religious council in Jalalabad, Afghanistan.

I am very happy that I have met Pamela Collett, Education Consultant of Save the Children (USA) at the Save the Children office in Mazar, Afghanistan. I became acquainted with your name and learned about your support for Afghan women through her.

Since you are a judge and an active member of the United Nations Human Rights Committee, I wanted to write to you about the lack of rights of women and children in Afghanistan.

I hope our voice will be heard and spread through the whole world through you and your work.

Dear sister,

Because of the civil war and the division of power among different parties and the lack of a central and powerful government in Afghanistan, the situation of our country is becoming worse. Illiteracy, poverty, illness and the lack of human rights, especially for women, are the main problems in our society. The current war has increased these problems and misery. Killing, looting, rape of women and girls are common occurrences in this country. Force and power are the law. In 1992, when the mujahadin took over from the communist regime, women became the miserable victims of all kinds of social, economic and legal problems.

The condition of children in Mazar-i-sharif,northern Afghanistan is very bad and nobody feels responsible. I would like to write about the situation of children. Some children because of the fighting, lost their parents and family members and became displaced to Mazar. They are homeless and walk around on the pavement of the shrine in Mazar, since they don't have shelter to spend the night. In order to keep from starving, they commit crimes in town such as stealing.

After being caught by security guards, their case is sent to the court for judgment to a special committee for children. According to the law, these children should be sent to Darul-tadeeb, which is a special prison for children to be taught for a period of time or be handed over to their parents or relatives. But unfortunately these children do not have family or relatives here and there is no Dar-ul-tadeeb. Also there is not any organization to look after these kind of children.

Once or twice a month, I face a woman in the court who is there for begging. One day, I asked a woman, why are you begging? She answered, "Before I came to Mazar I was living in Kabul. My husband was killed in the fighting and my son became a double amputee. We came to Mazar. I have two daughters, three nephews with daughters-in- 
law. We are nine members in the family. There is no one to provide us with food and so I have to beg."

All the properties and capital of our nation have been spent for the purpose of useless fighting and killing of brother by brother. It's three years that the government employees "have not been paid their salaries.

Fighting, refugees, lack of shelter, and lack of opportunity for work have placed everyone in a very bad situation. Especially for women and children, the situation is unbearable. We are concerned that because of the forgoing reasons, women beg on the streets, steal, sell themselves or commit other action against the law to save their lives. These people have committed a social crime, according tot he law. They should be punished because they violated social law. But here is no court to investigate and find out the main cause for their crimes.

Dear sister, I not only send this letter to you personally but also to you as supporter of human rights and the rights of women. I ask you again to let the voice of Afghan women and girls be heard by international organizations and those who have power to help stop the fighting in our land and bring a stable peace.

Especially the UN should not wait while our land becomes more damaged by war and our people are being sacrificed for politicians and their followers for their shameful purposes.

We have witnessed that foreign powers interfere in our country every day, increasing the flame of fighting and taking from us all our humanity, rights, purity and ethics. These elements are the soul of our society. When these things are removed, human society becomes meaningless. We want peace. The people of Afghanistan should be the governors of their own destiny. Everybody, including men and women should have equal rights and take part to build their own destiny.

Dear sister,

If you read this letter and find the opportunity to communicate with me, I will write to you more about the lack of women's rights in the courts.

Sorry for taking your precious time. Thank you.

signed, Fawzia, judge, provincial court, Mazar-i-sharif, Balkh Province, Afghanistan.

Translator's note: Fawzia is the only woman judge in the Balkh provincial court system, where there are about 40 male judges. She is concerned about the daily abuses of women's and children's rights that she sees in the court. She was encouraged by the news that people around the world are interested in supporting Afghan women's human rights. She decided to write a letter to Elizabeth Evatt, who is also a judge and is a member of the United Nations Human Rights Committee, thanking her for her concern. The original letter was handwritten in Dari. 
Seminar on Human Rights in Afghanistan

Cooperation Centre for Afghanistan (CCA)

Peshawar, Pakistan December 10-13 1995

\section{Presentation: Women's Human Rights in Afghanistan by Rukhshana Sarwar (Dari) and Pamela Collett (English) Save the Children (USA), Pakistan Afghanistan Field Office \\ Islamabad}

\section{Introduction: the international perspective}

What is the current status at the international level of women's and girls' human rights?

AI.I. UN documents affirm the equality of women and men. One of the earliest achievements of the UN was the Universal Declaration of Human Rights, 1948, which stated "whereas the peoples of the United Nations have in the Charter reaffirmed their faith in fundamental human rights, in the dignity and worth of the human person and in the equal rights of men and women..." YFT until very recently, women's human rights have been "invisible" or subject to limitation by prevailing male-biased cultural traditions.

A breakthrough for women and girls occurred at the World Conference on Human Rights, Vienna 1993 which reaffirmed that all human rights derive from the dignity and worth inherent in the human person, that is, they are the birthright of every human being. "The human rights of women and of the girl child are an inalienable, integral and indivisible part of human rights. The full and equal participation of women in political, civil, economic, social and international levels and the eradication of all forms of discrimination on the grounds of sex are priority objectives of the international community."

As Shanthi Dairiam, a Malaysian delegate to the Fourth World Conference on Women noted in the September 1995 edition of the UNFPA magazine "Populi", "Historically arguments of culture, religion and tradition in particular have heen used to deny women their rights. But the Vienna conference stressed the importance of 'working towards the elimination of gender bias in the administration of justice and the eradication of any conflicts which may arise between the rights of women and the harmful effects of certain traditional and customary practices, cultural prejudice and religious extremism.' "

Although Afghanistan has signed some international conventions, such as ICESCR, 1983, CELAW (not ratified), without a recognized central government, the conventions are not being observed

Challenge: UN human rights conventions should be disseminated to any interim government that may be established in Afghanistan and should be included in all future legislative processes.

Note: summaries in Dari and Pashto of all major human rights documents should he made available to government officials, UN agencies and NGO's. 


\section{Beijing, September, 1995: Fourth World Conference and NGO Forum on Women: perspectives on women's human rights around the world}

In Beijing and Hairou China, over 35,000 women and men gathered to review the progress made on the conditions and status of women and girls around the world. All UN member nations, except Saudi Arabia and Grenada, registered for the conference.

The main document of the Fourth World Conference on Women is the Platform of Action. Three sections of the Platform of action involved human rights: violence against women, impact of armed conflict on women and the human rights of women.

The Platform calls on the UN to integrate concern for human rights of women into all of its human rights activities.

The Platform recognizes that if women are to fully exercise their rights, they must be informed about those rights. Innovative programs need to be developed regarding social, political, and legal literacy for women to understand and exercise their rights.

Amnesty International urged that governments should give particular emphasis to gender education, to make women aware of their rights and to make society at large. conscious of their duty to respect the human rights and fundamental freedoms of women and girls.

A new section in the Platform for Action, introduced by African states, focused on eliminating discrimination and ensuring the rights of girls.

The International Save the Children Alliance, based on the UN Convention on the Rights of the Child, has affirmed that girls have equal value as human beings, that the best interests of girls should be primary, that the opinion of girls should be considered and that every girl has rights.

The Platform calls for equal access to education for women and girls and development of curricula free of gender stereotypes.

The largest UN conference ever held, the Fourth World Conference and the NGO Forum on Women further consolidated the gains of the Vienna conference and strengthened the view that human rights are all women's and girls' right and that these rights must be acknowledged as inherent, inalienable, indivisible and universal, calling for a series of governmental and non governmental actions to implement women's and girls' human rights.

There is a clearer awareness since the Vienna conference, which was furthered at Beijing, that the human rights of girl's and women have been ignored. Throughout the world, more attention is now being focused on women's and girls' human rights. Both of these conferences affirmed that they do not accept the use of tradition and culture as arguments that women do not have the same human rights as men.

Through email and fax, plus international media, it has become easier to communicate human rights violations around the world. Networks of international organizations to 
defend human rights and particularly human rights of women and girls exist. There is a new level of awareness and better communication since Beijing. Human rights are no longer seen as an internal matter for each state to decide. There is a well established level of international humanitarian concern, which includes women and girls.

\section{Women's Human Rights in Afghanistan: Summary}

focus on employment and education opportunities for girls and women and on vulnerable groups such as widows lack of legal protection breakdown of social protection due to ongoing civil war

\section{Women's Human Rights in Afghanistan: Advocacy}

In October, 1995, a report on Women's Human Rights in Afghanistan based on interviews with Afghan women and individuals working in Afghanistan, was submitted to Equality Now in New York, an international NGO for women's human rights, by Pamela Collett. The report was sent to the IN Human Rights Committee, which held a meeting in October in Geneva. The report was also sent to the New York Times by Equality Now. As a result of the report and the media attention, which noted, among other problems for women and girls, that during the past year UN agencies in Jalalabad had suspended Afghan women staff in response to a decree from a religious shura that women were not allowed to work outside the home, the UN has been investigating the situation of Afghan women's and girls' rights to employment and education.

In accord with the Convention on the Rights of the Child and its own charter which stipulates that there is to be no discrimination, UNICEF decided to suspend its programs in areas of Afghanistan where girls' were not allowed access to education. As a result of the report and the media response, international attention has been focused on the human rights of women and girls in Afghanistan.

Activities taken by Afghan Women's Network in Islamabad:

- Documentation for UN Human Rights Committee report, submitted by Pamela Collett

- Follow up letters to UN and media

- Letter writing campaign against harassment of Afghan community in Islamabad

- Newsletter

- Participation in women's seminar in Peshawar

- Communication with other women's groups in Afghanistan and Pakistan

- Ongoing training in communication and leadership skills

\section{Women's Human Rights in Afghanistan: Challenges and Actions}

Challenges:

1. Incorporation of UN Human Rights conventions into interim government and legislative actions

2. Fducation for human rights, specifically addressing gender issues

3. Fducation for women regarding their human rights in order to exercise their rights

4. Fmployment opportunities for women

5. Education opportunities for girls and women 
Proposed Actions related to these challenges:

1. UN human rights conventions:

- Work with the UIN, specifically the office of the special envoy to incorporate UN human rights conventions into any interim government, through education and advocacy with officials

- Work with any interim government, UN, NGO's to document Afghanistan's human rights situation for the UN Human Rights Committee in July 1996 to develop as

comprehensive a report as possible, with separate sections relating to women's and girls' human rights

- Document by NGO's and UN agencies, violations of women's and girls' human rif.its,

Responsibility for above actions: coordinated by CCA

2. Fducation for human rights:

- Develop, train resource people and implement human rights educational curricula with emphasis on gender issues for government officials, professionals, such as doctors, veterinarians, scientists, teachers, etc.

- Develop, train resource people and implement human rights educational curricula with emphasis on gender issues for schools at all levels

Responsibility for above actions: Governmental agencies working with UN agencies and NGOs, with support from CCA

3. Educate women about their human rights

- Develop, train resource people and implement human rights non formal education program for women regarding their rights and how to exercise them, with emphasis on reaching rural women

Responsibility for above actions: Governmental agencies working with UN agencies and NGOs, with support from CCA

4. Employment for women:

- Support women's rights to employment outside the home, including recruitment of women in all government, UN and NGO agencies

- No discrimination in employment

- Affirmative action for women and girls in skills training programs

- Provide appropriate transport and accommodation to allow participation of women and girls in training programs

Responsibility for above actions: Governmental agencies working with UN agencies and NGOs, with support from C.CA 
5. Education opportunities for girls and women:

- Equal access to education for girls and boys

- Advocate for girls' rights to education and training

- Recruit women for decision making positions in all educational institutions and ministries

- Develop curricula at all levels of education that are gender aware and educate about women's and girls' human rights

Responsibility for above actions: Governmental agencies working with UN agencies and NGO's with support from CCA

Who's to carry out these actions?

Government agencies

UN agencies

NGO's, local and international

Advocacy and networking groups

What's needed to prepare for these actions:

Training in gender, human rights, communication, and leadership skills for human rights advocates working in government agencies, universities, schools, UN agencies and NGO's.

\section{References:}

Amnesty International, "Fquality by the year 2000?", September 1994.

Dairiam, Shanthi, "Universal, indivisible, interdependent, interrelated...and in peril", Populi, the UNFPA Magazine, vol. 22, no. 7, September 1995.

Farth Negotiations Bulletin, Summary of the Fourth World Conference on Women, vol. 14. No.21, 18 September, 1995, International Institute for Sustainable Development

Fourth World Conference on Women Platform for Action, Beijing, 1995.

International Save the Children Alliance, "A Girl's Right to Development, Equality and Peace".

UN Human Rights Instruments:

- The Universal Declaration of Human Rights, 1948

- The International Covenant on Economic, Social and Cultural Rights, 1966.

- The Convention on the Flimination of All Forms of Discrimination against Women (CEDAW), 1979.

- The Convention on the Rights of the Child, 1989.

- Vienna Declaration and Programme of Action, 1993. 


\author{
Mahmoud Mectiri \\ UN Special Envoy to Afghanistan \\ OSGAP \\ 14 Nazimuddin Road F $8 / 1$
}

\title{
Dear Mr Mestiri
}

We are writing to you as a groun of Afghan women living in Islamabad who are concerned about the lack of women's participation in the peace process in Afghanistan.

As women are more than half the population in Afghanistan, we believe that peace is not possible without the active particjpation of women. We women have many respected roles in Afghanistan, including as peacemakers within our families. Peace begins in the family and then can spread out to the community and the country. Why should our rights to be involved in peare be denied? Women can help establish peace in Afghanistan.

We women are working as teachers, judges, lawyers, doctors, nurses and those not working outside are all working inside the family. Women are working in the fields, harvesting crops and taking care of animals. Women are working inside and outside the home. If we are capable of doing these things, why are we not capable of working to bring peace? Women can play an important part in the reconstruction of Afghanistan.

Women are also interested in peace, because we are the ones that suffer the most from war. It is our children, husbands, brothers and other relatives who are killed and wounded, while women continue with the responsibility to take care of their families. Most of the refugees are women and children. Many widows have the complete responsibility to care for their children and somehow provide them with food, housing, health care and education, which has become more and more difficult with the ongong war. Kabuli mothers are suffering herause their children have to huddle together under blankets because there is no fuel to heat their homes during the fierse winter.

We would like to share with you some of our ideas about how women could be involved in the peace process:

- Women's shuras for peace at the village level. These shuras could also be involved in monitoring violations of women's human rights.

- Women as mediators

- Women testifying for peare

- Women asking men to join them for a day of peace and prayer

- Women visiting shrines to pray for peare

- A day of fasting for peace

- A day of teaching only peare at all schools, colleges and universities

- Women and children joining hands to form a circle of peace at a specific location 
- A day of peace in the family: no harsh words or ill will and no gun play among boys; a day of comperation, sharing, and forgiveness of past disagreements with family and neighbors

- Newspapers, TV, radio: every Thursday focus on peace with articles on peace makers, peace initiatives, what people are doing for peace in their families and communities. Discuss what is peace.

- Training for women and men in mediation and non violent conflict resolution

- Women teaching peace and non violent conflict resolution in schools and clinics

We are willing to work on some of these ideas ourselves to encourage Afghan women and men to work for peace. But we believe that it is an urgent necessity for the United Nations to include women in the peace process to help create an environment where peace in Afghanistan becomes possible.

We urge the United Nations and the Office of the Secretary General to appoint a female representative to work with you in the peace process and on advisory committees to ensure the active participation of Afghan women and the guarantee of women's rights in any transitional accords. We suggest that the UN should appoint a woman who is experienced in the peace process. She would require the services of a well-qualified Afghan woman as translator. The translator should be someone who is not associated with any political parties. The female UN representative should meet with women in refugee camps, villages and cities in Afghanistan, Pakistan and Jran to discuss peace and hear their jdeas. Women should be encouraged to get involved in the peace process through these women's meetings by forming women's shuras or councils for peace.

We would appreciate a response from you or your office as soon as possible regarding our request. We would be happy to arrange a meeting with a group of Afghan women with you or someone from your office at your convenience to discuss this proposal.

Sincerely,

Afghan Women's Network

H. 195 St. 57 G $9 / 4$

Islamabad

contact person:

Rukhshana Sarwar work telephone: 220930

copies to:

Francis Okelo, OSGAP

David Lockwood, UNDP

Martin Barher, UNOCHA

Choong-Hyun Paik, Special Rapporteur of the UN Commission on Human Rights 


\section{April 1996}

to: Afghan Women's Network and Advisory Group

from: Rukhshana, Save the Children (USA)

Subject: Meellng with Ambassador Mestirl

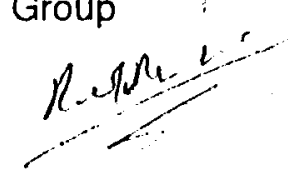

As a follow up to the letter we sent to Ambassador Mestiri on January 18, we are going to meet with him on Sunday April 7 at 11 a.m., 14 Nazimuddin Road, $F 8 / 1$, to discuss the involvement of Afghan women in the peace process.

To prepare for this important meeting, a pre-meeting planning session will be held at 9:30 a.m. at UNDP, 18 Nazimuddin Road, F 8/1. All the participants in the meeting with Mestiri are requested to attend the pre-meeting. We will discuss the issues to be presented in the meeting.

Please bring your notes on the following issues. We have assigned two people to each point in order to avoid repetition.

Thank you for your support. This is an important meeting for Afghan women.

1. Why Afghan women should be included in the peace process: Gulalai and Pamela

2. How Afghan women could be included: Rukhshana and Nefisa

3. What Afghan women are already doing for peace: Torpekai and Palwasha (or Nooria or Sodoba if Palwasha cannot attend)

4. What UN should do to include women in the peace process: Latila and Angela

copies:

Gulalai Habib, UNDP

Pamela Collett, Save the Children (USA)

Nefisa Nezam, UNOPS

Torpekai Ludin, Save the Children (USA)

Palwasha Hassan, AWEC

Nooria Kazimi, AWEC

Sodoba Timori, AWEC

Latifa Irshad, Focus Canada

Angela Kearney, Save the Children (U:iK) 
7 April 1996

to: Ambassador Mestiri

from: The Afghan Women's Network, Islamabad

Why women should be included in the peace process in Afghanistan:

As women are more than hall the population in Afghanistan, we believe that peace is not possible without the active participation of women. For any peace process to be effective it must include large numbers of the population, including women.

\section{Women and War}

Women suffer effects of war in a different way than do men. While most men are off fighting, women suffer the loss of family members, the loss of economic security, the loss of home, loss of health and education services in their daily life. Children, husbands, brothers and other relatives are killed and wounded, while women continue with the responsibility to take care of their families. Most of the refugees are women and children. It has been estimated that up to 1/3 of Afghan women are widows. Many widows have the complete responsibility to care for their children and somehow provide them with food, housing, health care and education, despite the ongoing war.

Women's involvement in making the war, in actual fighting, is only INDIRECT, as support for husbands, brothers, sons. Women could withdraw that support. They could advise male family members to STOP fighting. Women could pray for their male family members to stop fighting instead of just praying for them to survive the fighting. Women and children could influence male family members to stop fighting.

Women are not profiting from the war, that is they are not getting power, money, or positions as a result of the war. They are only experiencing the suffering and deprivation of war. Women are not corrupted by war in the same way as men. They are more in touch with the suffering of war. They are more involved with the struggle for daily survival. Most women are NOT involved with factions and political parties. Women can see another way to live without fighting and can encourage family members and colleagues to work for peace.

WAR has effected WOMEN differently than MEN. WOMEN are in a better position to work for, practice and believe in PEACE than are most men who are more directly involved with fighting and with power games. 
Women and Society

Women's position is society is different from men, giving them different skills and opportunities which could be used for peace.

Women in the family can be peacemakers, role models, and raise their children for peace. They can encourage children, especially boys NOT to play war games, not to fight, but to settle differences peacefully. Peace begins in the family and then can spread out to the community and the country. Women can help establish peace in Afghanistan.

Women working outside the home could be workplace advocates for peace. They have the opportunity, the interest and the skills. Women are working as teachers, judges, lawyers, doctors, and nurses and those not working outside are all working inside the family. Women are working in the fields, harvesting crops and taking care of animals. Women are working inside and outside the home. If women are capable of doing these things, why are they not capable of working to bring peace? Women can play an important part in the reconstruction of Afghanistan.

Women, Peace and Human Rights

Article 3 of the Universal Declaration of Human Rights, 1948, states:

"Everyone has the right to life, liberty and the security of person."

The term EVERYONE includes women. Women have these human rights but they are being denied by the ongoing war. To exercise our basic human right to life liberty and security, we must be involved in the peace process. Why should our rights to be involved in peace be denied?

Powerful individuals and groups inside and outside of Afghanistan are daily making decisions that threaten our life, liberty and security. We have a right to try to counter those individuals and groups by working for peace in our families, our communities, and our country.

Women need the active support of the UN to be effective in our work to bring peace to Afghanistan. 


\section{Records of the Meeting between Ambassador Mestiri (SESG), Members of the Gender Advisory Group in Afghanistan and Afghan Women's Network}

Date and Time:

7 April 1996, 11:00 hours

Participants' \& Organizations:
Ambassador Mestiri, Special Envoy of the Secretary General (SESG) Mr. Rieck, Political Advisor to the SESG
Col. Egar, Military Advisor to the SESG
Mr. F. Okelo, Director, OSGA
Ms. Pamela Collett, SCF (USA)
Ms. Rukhshana Sarwar, SCF (USA)
Ms. Torpekai Ludin, SCF (USA)
Ms. Angela Kearney, SCF (UK)
Ms. Palwasha Hassan, AWEC
Ms. Latifa Irshad, Focus Canada
Ms. Nafisa Nezam, UNDP/ARRP \&
Ms. Gulalai Habib, UNDP

Purpose: $\quad$ To follow up the letter dated 18 January 1996 addressed to Amb. Mestiri on Afghan women's participation in the peace process.

Facilitator - Ms. Latifa Irshad, Focus Canada

Venue: $\quad$ OSGA Afghanistan in Islamabad

Agenda Items: $\quad$ 1. Why Afghan women should be included in the peace process

2. How Afghan women could be included in the peace process

3. What Afghan women are already doing for peace

4. What the UN should do to include women in the peace process

5. Any other business (AOB)

\begin{tabular}{|c|c|c|c|c|}
\hline $\begin{array}{l}\text { Agenda } \\
\text { Item No. }\end{array}$ & Decision & $\begin{array}{l}\text { Person } \\
\text { Responsible }\end{array}$ & $\begin{array}{l}\text { Comple- } \\
\text { tion } \\
\text { Date }\end{array}$ & Status \\
\hline 1 & $\begin{array}{l}\text { The impact of war on women, the rule of } \\
\text { women, as mothers at home and as the bread } \\
\text { owner of the family at the present war affected } \\
\text { Afghan society, were explained. The need for } \\
\text { women's recognition and participation in the } \\
\text { peace process was confirmed. }\end{array}$ & & & \\
\hline 2 & $\begin{array}{l}\text { Women shuras to be established. Special } \\
\text { consideration to be given to the establishment of } \\
\text { widows organization. }\end{array}$ & $\begin{array}{l}\text { SESG/ } \\
\text { Network/ } \\
\text { Advisory } \\
\text { Group }\end{array}$ & $\begin{array}{l}\text { future } \\
\text { planning }\end{array}$ & $\begin{array}{l}\text { under } \\
\text { consideration }\end{array}$ \\
\hline
\end{tabular}




\begin{tabular}{|c|c|c|c|c|}
\hline 3. & $\begin{array}{l}\text { The establishment of Afghan Women's Network } \\
\text { and the UN/NGOs Gender Advisory Group were } \\
\text { discussed. The peace initiative through } \\
\text { distribution of questionnaires, encouragement of } \\
\text { school children for peace thoughts by paintings } \\
\text { and articles, were the possible positive aspects. } \\
\text { Number of peace paintings by the school children } \\
\text { and the result of questionnaire on peace were } \\
\text { offered to SESG as presents. }\end{array}$ & : & continued & $\begin{array}{l}\text {-similar } \\
\text { initiatives to } \\
\text { bring peace } \\
\text { from below to } \\
\text { be encouraged } \\
\text {-the SESG to be } \\
\text { informed of the } \\
\text { progress }\end{array}$ \\
\hline 4 & $\begin{array}{l}\text { SESG to consider the recruitment of a female } \\
\text { advisor (expatriate) and an Afghan female } \\
\text { translator, both to be in touch with Afghan } \\
\text { women from different groups to enforce women's } \\
\text { involvement in the peace process. } \\
\text { A letter to be sent to the Secretary General } \\
\text { regarding the importance of the above issue and } \\
\text { the interest of Afghan women for involvement in } \\
\text { the peace process with emphasis on the need for } \\
\text { recruitment a female advisor for the SESG. }\end{array}$ & $\begin{array}{l}\text { SESG } \\
\text { Ms. Sarwar } \\
\text { Network/ } \\
\text { Advisory } \\
\text { Group }\end{array}$ & $\begin{array}{l}\text { next } \\
\text { meeting } \\
\begin{array}{l}\text { as soon as } \\
\text { possible }\end{array}\end{array}$ & $\begin{array}{l}\text { proposal for } \\
\text { review \& action } \\
\text { by SESG } \\
\text { draft letter to be } \\
\text { reviewed and } \\
\text { finalized }\end{array}$ \\
\hline 5 & $\begin{array}{l}\text { The SESG showed interest to continue exchange } \\
\text { of information with the group. A follow up } \\
\text { meeting to be held in the new office of SESG in } \\
\text { Jalalabad. }\end{array}$ & $\begin{array}{l}\text { Mr. Okelo } \\
\text { OSGA }\end{array}$ & $\begin{array}{l}\text { after a } \\
\text { month }\end{array}$ & $\begin{array}{l}\text { date and time to } \\
\text { be fixed \& } \\
\text { announced }\end{array}$ \\
\hline
\end{tabular}




\section{April 1996}

Ambassador Mahmood Mestiri

UN Special Envoy to Afghanistan

OSGAP

14 Nazimuddin Rd F 8/1

Islamabad Pakistan

Dear Mr. Mestiri

Thank you very much for giving the Afghan women from the Afghan Women's Network and the Advisory Group on Gender Issues in Afghanistan an opportunity to discuss peace and the involvement of women in the peace process in a meeting with you and your colleagues Mr.Francis Okelo and Mr.Maureau on 7 April 1996.

At that meeting, we shared with you some of our ideas about how women could be involved in the peace process in Afghanistan including :

- women's shuras for peace at the village level

- women asking men to join them for a day of peace and prayer

- women visiting shrines to pray for peace

- A day of fasting for peace

- A day of teaching only peace at all schools, colleges and universities

- Newspapers, TV, radio : focus on peace with articles on peace makers peace initiatives, what people are doing for peace

- Training for women and men in mediation and non violent conflict resolution

-Women teaching peace and non violent conflict resolution in schools and clinics 
We appreciate your suggestion about Widows' Associations and will share this idea with women's groups in Pakistan and Alghanistan. However we think the women's shuras should incorporate widows and address widows' needs rather than isolating widows and their problems in a separate organization. We strongly urge you to follow up with the suggestion add a woman to your advisory team. We appreciate your suggestion of having regular consultation with woman 's groups in Afghanistan and Pakistan.

I would like to further discuss the process of formation of women's shuras. To form these shuras any where needs a lot of effort and practice. It will be a lengthy process. Whatever is done in this regard could be a great step towards peace and strengthens the mentality of bringing peace in Afghanistan. It is hard work but if there is a will and strong commitment it. could be done through the development programs of UN agencies and national and international NGOs. In Mazar-e-sharil, when the idea of making shuras was introduced and explained to the village women, they welcomed it warmly, especially when they realized that through these shuras they will be able to discuss their family and community problems. To form women's shuras, there are several steps to be considered in approaching the community:

- choosing carefully the areas where it would be possible to form the women's shura at lirst, based on the male and female communities acceptance of the idea.

- try to have a rural - urban balance, that is form shuras in rural as well as urban areas.

- getting information from UN agencies and NGOs working in those areas before going to the areas to see if it is possible to get women together. - investigate il there is a tradition of women's shuras or development of women's meetings through non-formal education and group guaranteed lending.

- to torm these women's shuras, UN and NGOs should approach the men first, asking permission to talk to women and ask if men would be interested to meet with the peace team.

- talking with women about women's shuras and giving training to women in planning meetings and train the women to prepare for the meetings. 
- having men and women meet in separate shuras in the same time frame with the peace team. The peace team should include women and men. Both women and men should meet with the male and the female shuras where possible.

We would like to discuss the steps in the process of forming women's shuras when we meet with you again in May in Jalalabad.

I express my hearty wishes and prayers for your success in this regard .

Sincerely yours,

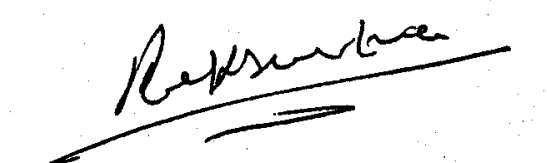

Rukhshana Sarwar

for the Afghan Women's Network

office phone: 220930

office fax: 220390 


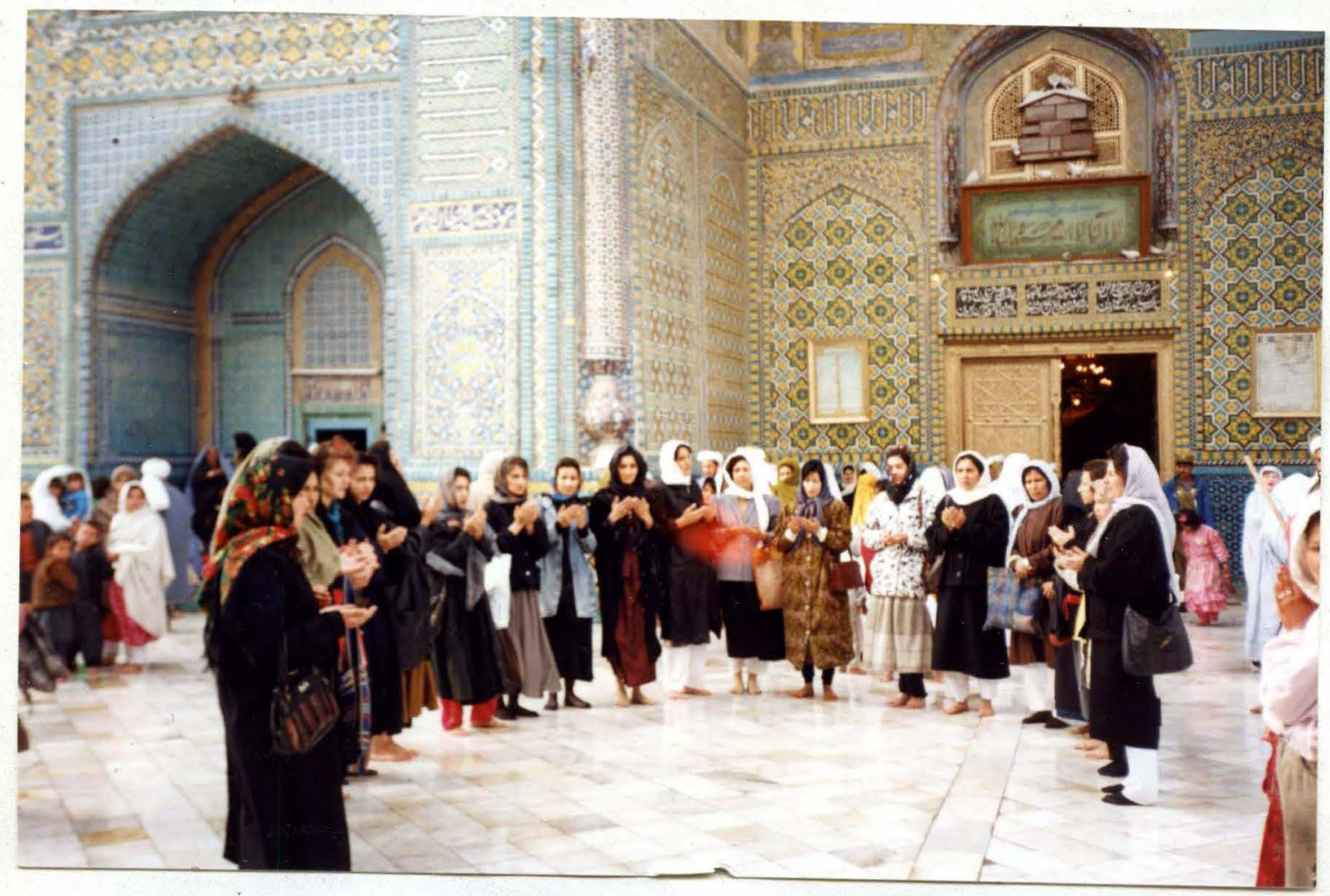

This photo shows a group of Afghan women who work in the literacy department in Balkh province standing in front of the Rawaz-e-sharif shrine in Mazar-i-Sharif. This shrine, which is that of Hazarat Ali, fourth caliph of Islam, is one of the most famous shrines in Afghanistan. On 27 March, 1996, the women gathered in front of the shrine, formed a circle and prayed for peace in Afghanistan 


\section{Activities for Deace by the Afghan Women's Network}

\section{Meeting with Ambassador Mestiri}

At a meeting in early January, 1996, the Afghan Women's Network decided to write a letter to Ambassador Mestiri, outlining the importance of including women in the peace process and requesting a meeting with him. The meeting was finally held on April 7, 1996. At the meeting, the Network explained their view of peace, as something built up slowly in communities, based on mutual respect, cooperation and human rights. The Network noted that this is a complementary process to the political process of stopping the fighting. Cessation of fighting does not equal peace. Peace will take time and effort to develop. All UN, NGO's and Afghan groups and individuals interested in peace need to cooperate if a basis for a lasting peace is to be built.

At the meeting, the Network urged Ambassador Mestiri to have a woman join his peace team. A female representative of the UN Special Mission with the help of UN and NGO agencies could arrange a series of meetings with women to discuss their views on peace. Such a series of meetings could be part of a process of organizing women's shuras for peace and human rights.

The Network also urged Mestiri to consult regularly with women and women's organizations. They hope to meet with him again in the month of May in Jalalabad, where he has moved his office. Mestiri encouraged the Network to contact other UN officials, including the Secretary General Boutros Boutros Ghali to discuss the importance of including women in the peace process in Afghanistan.

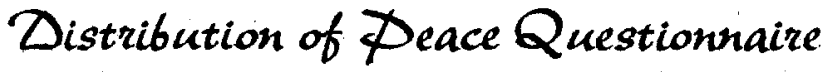

In order to stimulate discussion within the Afghan community, the Afghan Women's Network started a peace questionnaire. This questionnaire is being circulated among the Afghan community in Islamabad, Peshawar, and Mazar. The Afghan Women's Network hopes that individuals and organizations will spontaneously spread the idea of the peace questionnaire among Afghans to help initiate a grassroots discussion and thinking about peace. Some of the suggestions from the questionnaires were presented to Ambassador Mestiri. Comments about the peace process are also being published in the Afghan Women's Newsletter.

The following is a translation of the peace questionnaire, which is being circulated in Dari:

\section{Deace Questionnaire}

War has continued for 18 years in Afghanistan and has had a very negative impact on all aspects of Afghan society. That is why women in Islamabad have formed a group and has 
prepared a questionnaire on peace. The Afghan Women's Network and this questionnaire are not related to any political parties. This project is done by volunteers to encourage people to think about peace and make suggestions for the improvement of the lives of all Afghans.

Please give us your ideas on the following questions:

- What is peace?

- What can women do for peace?

- What can men do for peace?

- What can children do for peace?

Peace booklet

Several members of the Afghan Women's Network work as teachers. They have requested their students to write about peace and to make drawings about peace. A group of teachers and parents will select some of the writings and drawings and put them in a booklet. Funds are needed to photocopy the booklet so it can be distributed to families and interested individuals and organizations.

\section{Deace $\not$ osters}

Members of the Afghan Women's Network have asked students to make posters about peace. Three of these posters were presented to Ambassador Mestiri on April 7. Other posters will be reprinted in a UN magazine being published in Islamabad. The Network is seeking funds or assistance in having the posters mounted for display and space to have an exhibition.

\section{Land mine Action Month}

During the month of Sawr (April 21 - May 21) the Afghan Campaign to Ban Land mines is sponsoring Land mine Action Month. The Afghan Women's Network has distributed information about the month's activities and encouraged teachers and students to participate in the poster contest. An article about land mines will be published in the next Afghan Women's Network newsletter. 
Survey of replies to Peace Questionnuire circulated by the Afghun Wonten's Network in Islaniabad taken from 50 questionnaires.

7 April, 1996

\section{Comments from Afghuns on the peince process:}

- Afghans are strongly demanding peace. They have suffered more than enough.

- A solution to the war and how to facilitate the peace process should begin at the national level with the help of international organizations.

Afghans are counting on the role of United Nations to solve the Afghans' problems which was created by outside forces, but it seems that the UN is not much interested in this issue. We would like the UN to take the responsibility and manage the following: 1-collection of weapons, 2-establishing a temporally govennent, 3-bring unity among A fighans through dialogues and negotiation at the national level, 4-elections.

- Peace is a sweet fruit which has been eaten by Afghan leaders and does not exist any more.

- Afghans need awareness and organization to help start work on peace. Many people wrote that they are ready to do something for peace but these need to be organization to work systematically for peace.

- $\quad$ "Please help us to bring peace to our country even it is by force! We are fed up. Just imagine for 18 years war...."

UN has not paid attention to the problem of Alghan children's education and their need for a peaceful enviromment.

The real participation of different ethnic groups is necessary in seeking peace in Afghanistan.

Women were not the couse of war and instability. Why they are so deprived now? Why do you not let them share in peace process?

- Afghan leaders should be sent ont of Afghanistan for five years. They should not be allowed to live even in the neighboring countries.

- Children are the main victims of war. They have no access to education, neither do they have hen tha hacilities. The eches of their voices should be spreatd all over the

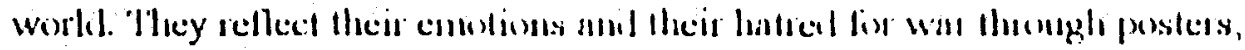
drawings, articles, shows, and through their behonvior.

Sone people suggest to inchude a sulject in the name of 'peace' in the children's schosl curriculum 
Peace

I know what is mine, or tank, or klashinkov. But,

-I don't know what does peace look like: Because I have not seen. it. I have just heard of it from others.

I know lots of weapons. For, I have seen almost all of them in the bazaar, the streets, on the walls of my school, in front of my house, in the buses, and every where else.

Some people say 'peace' is a bird; and some say it is luck. I dort know how does it come:" But, I know whenever peace comes, flowers will be planted instead of mines. No schools will be closed and no houses will be leveled with the ground, and I will not cry for persons killed.

When peace comes people can easily go home and live in their own houses; and by then, no gunman will ask them "What do you do here?" Because the will go to their own houses, and again nobody will ask them "What do you do in your own house?".

When peace comes, I will see what does it look like. I am sure, I will then forget the names of the all the weapons I know.

by: The third class $-\dot{B}$ name - students grade - 3B schorl - khorana 
ZOHRA Amon Marooti.

CLASS: 7 th.

$A G E: 11$.

School: Malabar islamabad PEACE W W H H W
Date: 7.4 .76

IN LIFE OF MANKIND AND hUMANS

THERE ARE TWO SCHOOLS:

ONE IS PEACE AND OTHER IS WAR:

Peace is the valuable idea which

remains durable. But wore is reactionery

and unwanted. PEACE based in the world is the best! Dead disasterous.

war in the world is the worst!

Humans in light of peace and freedom

will face: a: big benifit theoritically and We are

mentally. Asking the U.N. And all peacelovers to assist Afghanistan in bringing peace all over the countryand build that ruined land. 